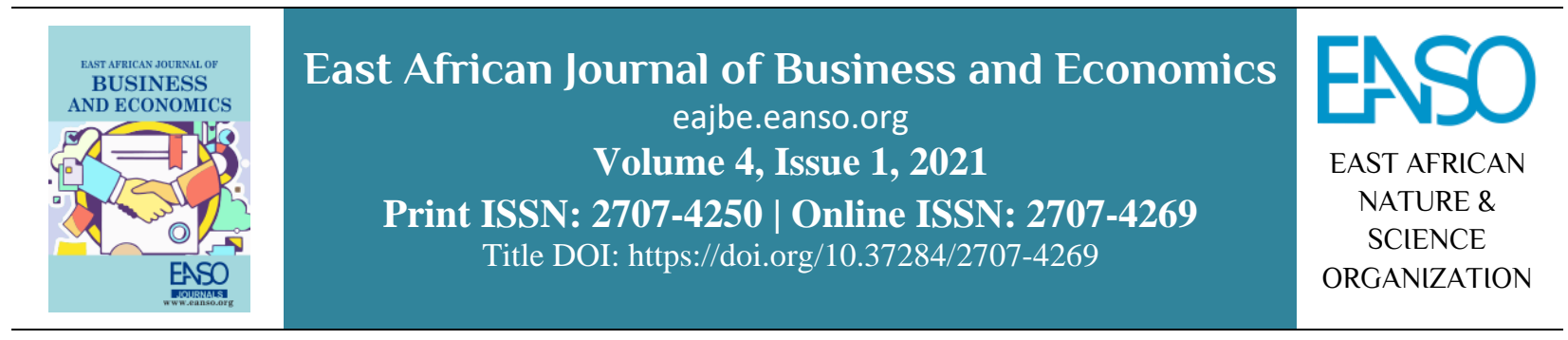

Original Article

\title{
Inventory Audit and Supply Management: An Evidence of Inventory Control Practices.
}

\author{
Bilha Saro ${ }^{*}$, Dr. Pauline Keitany, $\mathrm{PhD}^{1}$, Dr. Williter Rop, $P h D^{1}$ \\ ${ }^{1}$ University of Kabianga, P. O. Box 2030 - 20200, Kabianga, Kenya. \\ *Correspondence email: bilhapatel@gmail.com.
}

Article DOI: https://doi.org/10.37284/eajbe.4.1.503

\section{Date Published: ABSTRACT}

13 December 2021 Supply management is increasingly becoming a focus in this 21 st century. For an organisation to compete and successfully operate in the current risky

Keywords: supply management atmosphere, it must apply control measures that are

Inventory Audit, Supply Management, Correlation Research

Design, Kenya. effective within its internal supply management. The supply management environment today is characterised by many risk factors that may have a negative impact on the inventory control operations of an enterprise. However, there is an outcry in the universities procurement sector for inadequate stock control. The paper aims to establish the relationship between inventory audit and supply management in public and private universities in Nakuru County. The study was guided by stock diffusion. The study adopted a correlation research design. The target population of this study was 115 employees drawn from the procurement department from Egerton and Kabarak University since their headquarters are found in Nakuru County. Multistage sampling procedure was used to select the respondents of the study from the two Universities. Taro Yamane's formula was used to obtain a sample size of 89 respondents. The data were analysed using both quantitative and inferential statistics. Findings revealed that inventory audits were efficiently done. This was improved by ensuring accuracy in recording. The universities also ensure that costs are well controlled to reduce waste and mismanagement of resources in the universities. The inventory audit was also done periodically to ensure all university property and resources were secured. Hence, there existed a significant relationship between inventory audit and supply management $(\mathrm{R}=0.836, \mathrm{P}<0.05)$. The study concluded that inventory auditing had a significant influence on supply management. The study recommended that the universities had room for the elimination of 
East African Journal of Business and Economics, Volume 4, Issue 1, 2021

Article DOI: https://doi.org/10.37284/eajbe.4.1.503

shortages, losses and wastage through periodic inventory audits. The universities should also adopt an electronic inventory management system that can make tracking easy.

APA CITATION

Saro, B., Keitany, P., \& Rop, W. (2021). Inventory Audit and Supply Management: An Evidence of Inventory Control Practices. East African Journal of Business and Economics, 4(1), 85-92. https://doi.org/10.37284/eajbe.4.1.503

\section{CHICAGO CITATION}

Saro, Bilha, Pauline Keitany, \& Williter Rop. 2021. "Inventory Audit and Supply Management: An Evidence of Inventory Control Practices.” East African Journal of Business and Economics 4 (1), 85-92. https://doi.org/10.37284/eajbe.4.1.503

\section{HARVARD CITATION}

Saro, B., Keitany, P., \& Rop, W. (2021) "Inventory Audit and Supply Management: An Evidence of Inventory Control Practices”, East African Journal of Business and Economics, 4 (1), pp. 85-92. doi: 10.37284/eajbe.4.1.503.

\section{IEEE CITATION}

B. Saro., P. Keitany., \& W. Rop. "Inventory Audit and Supply Management: An Evidence of Inventory Control Practices", EAJBE, vol. 4, no. 1, pp. 85-92, Dec. 2021.

\section{MLA CITATION}

Saro, Bilha, Pauline Keitany, \& Williter Rop. "Inventory Audit and Supply Management: An Evidence of Inventory Control Practices". East African Journal of Business and Economics, Vol. 4, no. 1, Dec. 2021, pp. 85-92, doi:10.37284/eajbe.4.1.503

\section{INTRODUCTION}

The supply management environment is identified with many factors that are risk and may impact unfavourably on the inventory control enterprise operations. For an institution to compete and run successfully in the modern supply of risk management environment, effective control measures should be put in place within its internal supply management in an organisation. Kravchenkova and Posazhennikova (2012) revealed that one of the ways that are adopted currently by enterprises is the growth of inventory control system that is effective. Irrespective of the scope, size or location of operation inventory control has continued to be an area of interest to every business due to the costs associated with it. Inventory control accounts for forty-five to ninety percent of total organisational expenses (Geda, 2016). Moreover, this inventory control can be applied as a tactical plan by an organisation to realise more effectiveness and efficiency in the daily running and intensify management of resources; internal processes, tracking of items across the organisation and smooth operations internally can be streamlined by the use of inventory control which in turn help improve organisation internal efficiency (Oballah, 2015).
Globally, inventory Control in every organisation is currently crucial for smooth running. Based on the external environment operation, organisations adopt various inventory control practices. Inventory control practices in Canada have become popular in both private and public organisations. A study done by Tian (2017) on inventory control framework audit done internally showed that place processes, practices, procedures and controls had been put in place appropriately in Canada for the inventory of election supplies to be managed.

According to Pan et al. (2015), organisations are developing inventory control systems at an increasing rate and adopting systems that can solve procurement challenges currently. Yadav (2015) further pointed the relating challenges in terms of selection of suppliers, high cost of inventory, delivery challenges, stock obsolescence and as well as stock-out. It is clear that emergency buying is common in most of the universities' procurement practices as compared to the public laws of procurement as proper procurement procedures are not fully followed (Chemjor, 2015). Therefore, the study focused on establishing the relationship between inventory audit and supply management in public and private universities in Nakuru County.

Inventory control shows the amount that is available at a given time and how you make a follow-up of it. 
It is applicable to every material that aid in the production of a product be it from raw materials to finished product. At every production stage process, it covers stock from the time it is bought to delivery to applying stock reordering. Successful control of stock gives one to own the right quantity of stock at the right time and place. It makes sure that the capital is not necessarily tied up, and in case challenges arise, it protects production in the supply management (Yadav et al., 2016).

Inventory control is not only used by businesses to enable timely material availability but also to make sure there is a satisfactory service provision to gain a competitive advantage. Internal inventory practices are used by many organisations to attain organisational goals and objectives to improve procurement operations. These inventory demands are achieved through the procurement departments in the organisation. Procurement thus is important in the provision of necessary goods and services to the customers in an organisation by maintaining the level of stock at the most minimal costs possible. The essential of inventory control is linked directly to how an organisation is successfully giving services to its customers. There has been an outcry in the universities procurement sector for lack of efficiency in their stock control.

According to World Economic Reports and Social Survey 2019 indicate that there have been many challenges in coming up with a sound way of establishing the level of the stock required that guarantee free flow goods and services without attracting a lot of resources in stocking such materials and without necessary rendering any single stock out of date. Although many organisations have integrated inventory control practices into their management, there is limited knowledge on the relationship between inventory control practices and supply management. The researcher therefore isolated this gap as a topic of interest and analyse such a relationship.

The study therefore intends to investigate the relationship between inventory control practices and supply management in public and private universities in Nakuru County, Kabarak and Egerton Universities which are private and public, respectively. The Universities were appropriate for the generalisation of Kenyan Universities. The main objective is to establish the relationship between inventory audit and supply management in public and private universities in Nakuru County

\section{LITERATURE REVIEW}

\section{Theoretic Review}

Stock diffusion theory was used to anchor the relationship between stock audit and supply management. Stock Diffusion theory was founded by Braglia, Gabbrielli and Zammori (2013). It outlines the approaches used in controlling inventories in an organisation. According to the theory, utilisation of stock is modelled as a Markov process that has a diffusion term that is slow. Fokker Planck model is applicable when calculating the chances of dissemination of reordering time and stock utilisation. Braglia et al. (2013) argued that it makes it possible to keep safety stock at a low level of inventory management is disbursed in this way. Similarly, according to Eaton and Kortum (1999), posited that it makes sure that lower levels are kept without interfering with the operational or internal organisation of the inventory costs.

Replenishment of stock is driven by policies in the public procurement which entails the Asset Disposal Act and Public Procurement, 2015. Stock control shows the amount of stock that an enterprise should contain at any given time and it makes sure that the level of stock are maintained by acquiring materials. There is a need to develop control of inventory system in such an uncertain environment that enables a real and direct flow of information that is timely on materials; information flow between the organisation and suppliers. This theory has a link with the study as it makes sure that every organisation shall develop internal structures, procedures and policies in which it is based on all inventory control operations (Eaton \& Kortum, 1999).

\section{Empirical Review}

Inventory audit is believed to be a concept of inventory management and accounting practitioners. Onchoke and Wanyoike (2016) argued that audit of inventory in any organisation ensures that there is an adequate and efficient analysis of inventories. Audit of inventory reduces 
the loss in inventories and enables the accuracy of inventory. According to Johnstone et al. (2013) audit of inventory ensures that an organisation do away with those risks which are related to inventory; inaccurate and incomplete inventory records, poor inventory security, unnecessarily high inventory levels, obsolete inventory and inadequate and inappropriate inventory.

It is beneficial to take into consideration audit of factors such as the costs used in the control of inventory systems and practices rather than auditing inventory control practices. Moreover, it is of benefit if an audit is carried out at the level of conformity with industrial and organisational practices of procurement. According to Monczka, Handfield, Guiunipero and Patterson (2015), practices in inventory control should go hand in hand with the direction of the organisation strategic, internal procurement and store's objective. Audit of inventory control if managed very well can lead to enhanced control of procurement successfully and in return procurement performance.

Audit of inventory control takes into consideration both procedures and policies put down and generated to make sure they comply with industrial standards and organisational, whether there is communication and proper understanding of inventory control policies and procedures by those employed implementing it, whether controls are in order to successfully undertake risk management that is in line to inventory control, whether there is body that looks on it and if it receives crucial information regularly allow for proper monitoring of goals, plans and results that are in line to inventory control, and if the results expected in inventory control are defined soundly and a follow up made (Eckerson, 2010).

Onchoke and Wanyoike (2016) in their research, analysed the determinants of inventory control practices and procurement performance of Agrochemical Distributors in the sub-county of Nakuru Central. It surveys the existing correlation between procurement performance and internal control specifically in the field of agrochemical distribution. The research used a cross-sectional survey design in that the research was conducted at a single time and the primary data was collected. The study targeted all employees working in distributing firms. The instruments for the collection of data were structured questionnaires, and data were analysed using both descriptive and inferential statistics. The results from the study indicated a significant effect of inventory audit practice on procurement performance. Lewis and Media (2014) postulated that the sole importance of embracing inventory audit is to enhance timely as well as enough identification of inconsistencies and evaluation. The study found that by conducting an Inventory audit, there are minimal inventory losses since accuracy has been greatly enhanced. Hence there is a reduction of any imbedding risks not limited to inappropriate and inadequate inventory, high inventory levels that are unnecessarily incomplete and inaccurate inventory records, inadequate security of inventory and out of date inventory. Therefore, the current study, while hinging on these findings as a continuation of the reviewed study, sought to probe the correlation between inventory control practices and supply management in public and private universities.

Radosevic et al. (2013) examined an internal audit of the supply chain management. The supply chain was examined based on the function of reducing the cost of the company. However, an internal audit of the supply chain remains a powerful tool in the reduction of operation cost and provide a competitive advantage in the global market in times of economic crisis. The study purpose was to examine internal audit activities in assessing risk and analysing the functioning of the supply chain. Internal audit is crucial in making recommendations for enhancing the effectiveness and efficiency of operations and ensuring that management attained the set goals. The paper found that internal audits enhance supply management in reducing the cost of the companies. The current study focused on examining the effect of internal audits on supply management.

\section{RESEARCH METHODOLOGY}

The study used a correlational research design. The study was done in private and public universities established within Nakuru County. The study was done in Nakuru County which is the representation of universities all over Kenya. The target population was 72 procurement officers and 43 store clerks, where 47 were from Kabarak University, and 68 
were from Egerton totalling 115 participants. A multistage sampling procedure was employed in the study. In the first stage, a purposive sampling procedure was employed to select the two institutions in the County which include Egerton and Kabarak. In the second stage, the stratified sampling technique helped select respondents who took part in the study. A sample of 36 and 53 from Kabarak University and Egerton University, respectively making a sample of 89 respondents. The study employed questionnaires to collect primary data. Descriptive statistics describe patterns and general trends in a set of data. A linear regression model was considered appropriate as an inferential tool that established the relationship between the variables. A research permit was obtained from the University of Kabianga IERC.
The letter was used to apply for a permit from the National Commission of Science, Technology and Innovation (NACOSTI). Ethical standards pertaining to the respondents and conduct of research was adhered to throughout the research process.

\section{RESULTS AND DISCUSSION}

In order to determine the relationship between inventory audit and supply management in public and private universities in Nakuru County, descriptive analysis was conducted. The analysis entails descriptive statistics results for inventory audit were analysed using mean and standard deviation. The summary results are presented in Table 1.

Table 1: Descriptive Statistics for Inventory Audit

\begin{tabular}{|c|c|c|c|c|c|c|c|c|c|c|}
\hline Statement & & SA & $\mathbf{A}$ & $\mathbf{N}$ & D & SD & Min & Max & Mean & $\begin{array}{l}\text { Std } \\
\text { Dev }\end{array}$ \\
\hline $\begin{array}{l}\text { University conduct inventory } \\
\text { audit efficiently }\end{array}$ & $\begin{array}{l}\% \\
\mathrm{f}\end{array}$ & $\begin{array}{l}25.0 \\
19\end{array}$ & $\begin{array}{l}53.9 \\
41\end{array}$ & $\begin{array}{l}21.1 \\
16\end{array}$ & $\begin{array}{l}0.0 \\
0\end{array}$ & $\begin{array}{l}0.0 \\
0\end{array}$ & 1 & 5 & 4.039 & 0.6819 \\
\hline $\begin{array}{l}\text { Inventory audits are done well to } \\
\text { ensure accuracy in recording }\end{array}$ & $\begin{array}{l}\% \\
\mathrm{f}\end{array}$ & $\begin{array}{l}19.7 \\
15\end{array}$ & $\begin{array}{l}44.7 \\
34\end{array}$ & $\begin{array}{l}25.0 \\
19\end{array}$ & $\begin{array}{l}10.5 \\
8\end{array}$ & $\begin{array}{l}0.0 \\
0\end{array}$ & 1 & 5 & 3.736 & 0.8999 \\
\hline $\begin{array}{l}\text { Costs are well controlled to ensure } \\
\text { reduction of wastage and } \\
\text { mismanagement of resources in } \\
\text { the university. }\end{array}$ & $\begin{array}{l}\% \\
\mathrm{f}\end{array}$ & $\begin{array}{l}26.3 \\
20\end{array}$ & $\begin{array}{l}39.5 \\
30\end{array}$ & $\begin{array}{l}18.4 \\
14\end{array}$ & $\begin{array}{l}15.8 \\
12\end{array}$ & $\begin{array}{l}0.0 \\
0\end{array}$ & 1 & 5 & 3.763 & 0.9180 \\
\hline $\begin{array}{l}\text { Inventory audits are done } \\
\text { periodically to ensure all } \\
\text { university property and resources } \\
\text { are secured }\end{array}$ & $\begin{array}{l}\% \\
\mathrm{f}\end{array}$ & $\begin{array}{l}9.2 \\
7\end{array}$ & $\begin{array}{l}51.3 \\
39\end{array}$ & $\begin{array}{l}23.7 \\
18\end{array}$ & $\begin{array}{l}15.8 \\
12\end{array}$ & $\begin{array}{l}0.0 \\
0\end{array}$ & 1 & 5 & 3.539 & 0.8708 \\
\hline $\begin{array}{l}\text { Inventory audits have ensured that } \\
\text { there is sufficient inventory } \\
\text { turnover to avoid shortages, losses } \\
\text { and wastage. }\end{array}$ & $\begin{array}{l}\% \\
\mathrm{f}\end{array}$ & $\begin{array}{l}21.1 \\
16\end{array}$ & $\begin{array}{l}30.3 \\
23\end{array}$ & $\begin{array}{l}32.9 \\
25\end{array}$ & $\begin{array}{l}10.5 \\
8\end{array}$ & $\begin{array}{l}5.3 \\
4\end{array}$ & 1 & 5 & 3.513 & 0.9014 \\
\hline Aggregate & & & & & & & & & .718 & 0.7156 \\
\hline
\end{tabular}

According to the results in Table 1 majority of the respondents $(41,53.9 \%)$ agreed that the universities conduct adequate inventory audit efficiently, while $19(25.0 \%)$ of the respondents strongly agreed and $16(21.1 \%)$ of the respondents were neutral $(M=$ $4.039, S D=0.6819)$. It was also revealed that the majority of the respondents $(34,44.7 \%)$ agreed that the inventory audit was done well to ensure accuracy in recording, while $19(25.0 \%)$ were neutral, 15(19.7\%) strongly agreed, and few (8,
$10.5 \%)$ disagreed $(M=3.736, S D=0.8999)$. The results indicated that the majority of the respondents $(30,39.5 \%)$ agreed that cost was controlled to ensure reduction of wastage and mismanagement of resources in the university, $20(9.2 \%)$ strongly agreed, $14(23.7 \%)$ were neutral, and $12(15.8 \%)$ disagreed $(M=3.763, S D=0.9180)$. The majority of the respondents $(39,51.3 \%)$ agreed that inventory audit was done periodically to ensure all university property and resources were secured; 
however, 18 (23.7\%) were neutral, 12 (15.8\%) disagreed and $7(9.2 \%)$ strongly agreed $(M=3.539$, $S D=0.8708)$. Finally, findings revealed that the majority of the respondents $(25,32.9 \%)$ were neutral that the inventory audit had ensured that there is sufficient inventory turnover to avoid shortages, losses and wastage, 23(30.3\%) agreed, 8 $(10.5 \%)$ disagreed and $4(5.3 \%)$ strongly disagreed $(M=3.513, S D=0.9014)$.

In overall, inventory audit was practices in the organization $(M=3.7184, S D=0.71567)$. According to Lewis and Media (2014) concur that audit of inventory assisted in increasing efficiency and enables accuracy in inventory management. Audit of inventory assisted in reducing out date inventory and minimising losses which is similar to the current study. The inventory control practice has assisted in enhancing efficiency and effectiveness in procurement, according to Onchoke and Wanyoke (2016), which concurs with the current study.

Supply management was analysed using mean and standard deviation based on a Likert scale of 1 to 5 from strongly disagree to strongly agree. The results summarised are presented in Table 2.

Table 2: Descriptive Statistics for Supply Management

\begin{tabular}{|c|c|c|c|c|c|c|c|c|c|c|}
\hline Statements & & SA & $\mathbf{A}$ & $\mathbf{N}$ & D & SD & Min & Max & Mean & $\begin{array}{l}\text { Std } \\
\text { Dev }\end{array}$ \\
\hline $\begin{array}{l}\text { There is sufficient inventory } \\
\text { turnover which has improved } \\
\text { supply management in the } \\
\text { institution. }\end{array}$ & $\begin{array}{l}\% \\
\mathrm{f}\end{array}$ & $\begin{array}{l}10.5 \\
8\end{array}$ & $\begin{array}{l}50.0 \\
38\end{array}$ & $\begin{array}{l}25.0 \\
19\end{array}$ & $\begin{array}{l}14.5 \\
11\end{array}$ & $\begin{array}{l}0.0 \\
0\end{array}$ & 1 & 5 & 3.565 & 0.8692 \\
\hline $\begin{array}{l}\text { Appropriate lead-time are always } \\
\text { given to avoid a shortage of } \\
\text { resource. }\end{array}$ & $\begin{array}{l}\% \\
\mathrm{f}\end{array}$ & $\begin{array}{l}30.3 \\
23\end{array}$ & $\begin{array}{l}28.9 \\
22\end{array}$ & $\begin{array}{l}21.1 \\
16\end{array}$ & $\begin{array}{l}19.7 \\
15\end{array}$ & $\begin{array}{l}0.0 \\
0\end{array}$ & 1 & 5 & 3.697 & 0.8077 \\
\hline $\begin{array}{l}\text { The university has operated } \\
\text { efficient and effective. }\end{array}$ & $\begin{array}{l}\% \\
\mathrm{f}\end{array}$ & $\begin{array}{l}9.2 \\
7 \\
\end{array}$ & $\begin{array}{l}50.0 \\
38 \\
\end{array}$ & $\begin{array}{l}15.8 \\
12 \\
\end{array}$ & $\begin{array}{l}19.7 \\
15 \\
\end{array}$ & $\begin{array}{l}5.3 \\
0 \\
\end{array}$ & 1 & 5 & 3.381 & 0.8704 \\
\hline $\begin{array}{l}\text { There are adequate inventory in } \\
\text { the university at all times }\end{array}$ & $\begin{array}{l}\% \\
\mathrm{f}\end{array}$ & $\begin{array}{l}9.2 \\
7\end{array}$ & $\begin{array}{l}35.5 \\
27\end{array}$ & $\begin{array}{l}28.9 \\
22\end{array}$ & $\begin{array}{l}21.1 \\
16\end{array}$ & $\begin{array}{l}5.3 \\
4\end{array}$ & 1 & 5 & 3.223 & 0.8532 \\
\hline $\begin{array}{l}\text { Inventory has enabled the } \\
\text { university to manage resources } \\
\text { and establish a steady supply. }\end{array}$ & $\begin{array}{l}\% \\
\mathrm{f}\end{array}$ & $\begin{array}{l}25.0 \\
19\end{array}$ & $\begin{array}{l}34.2 \\
26\end{array}$ & $\begin{array}{l}26.3 \\
20\end{array}$ & $\begin{array}{l}9.2 \\
7\end{array}$ & $\begin{array}{l}5.3 \\
4\end{array}$ & 1 & 5 & 3.644 & 0.9159 \\
\hline
\end{tabular}

Accordance to the results in Table 2, majority of the respondents $(38,50.0 \%)$ agreed that inventory turnover improved supply management in the institution, while $19(25.0 \%)$ were neutral, 11 $(14.5 \%)$ disagreed and $8(10.5 \%)$ strongly agreed $(M=3.5658, S D=0.8692)$. Also, majority of the respondents $(23,30.3 \%)$ strongly agreed that appropriate lead time was always given to avoid shortage of resource, where $22(28.9 \%)$ agreed, 16 $(21.1 \%)$ were neutral and $15(19.7 \%)$ disagreed $(M$ $=3.697, S D=0.8077)$. Furthermore, majority of the respondents $(38,50.0 \%)$ agreed that university had somewhat operated efficient and effective, however, 15(19.7\%) strongly agreed, 12(15.8\%) were neutral and $7(9.2 \%)$ strongly agreed $(M=$ 3.381, $S D=0.8704)$.
However, majority of the respondents $(27,35.5 \%)$ strongly always agreed that adequate inventory in the university, 22 (28.9\%) were neutral, $16(21.1 \%)$ disagreed, 7(9.2\%) strongly agreed and $4(5.3 \%)$ strongly disagreed $(M=3.223, S D=0.8532)$. Finally, findings indicated the majority of the respondents $(26,34.2 \%)$ agreed that the inventory had somewhat enabled the university to manage resources and establish a steady supply, $20(26.3 \%)$ of the respondents were neutral, $19(25.0 \%)$ strongly agreed, $7(9.2 \%)$ disagreed and $4(5.3 \%)$ strongly disagreed $(M=3.644, S D=0.9159)$. The performance of supply management was somehow high in the university $(M=3.502, S D=0.8929)$.

Correlation analysis was examined to ascertain the interrelationship between variables at 5\% 
significant level. The summary results are presented in Table 3.

Table 3: Correlation Analysis

\begin{tabular}{llll}
\hline & & Inventory Audit & Supply Management \\
\hline \multirow{3}{*}{ Inventory Audit } & Pearson Correlation & 1 & $.839^{* *}$ \\
& Sig. (2-tailed) & 76 & .000 \\
& $\mathrm{~N}$ & 76 \\
\hline \multirow{3}{*}{ Supply Management } & Pearson Correlation & 1 \\
& Sig. (2-tailed) & & 76 \\
\hline
\end{tabular}

Table 3 results inventory audit had strong positive significant relationship with supply management $(R$ $=0.836, p<0.05)$.

The first null hypothesis which examined if there is no significant relationship between inventory audit and supply management in public and private universities in Nakuru County was rejected. According to the results there existed a significant relationship between inventory audit and supply management in public and private universities in Nakuru County $(p<0.05)$. Onchoke and Wanyoike (2016) also found that there existed a significant relationship between inventory audit practices and procurement performance. Even though the study was done in agrochemical distributors within Nakuru Central. Similarly, Lewis and Media (2014) pointed that inventory audits assisted in improving efficiency in the supply chain.

\section{CONCLUSIONS AND} RECOMMENDATIONS

\section{Summary}

Inventory audit was efficiently conducted in the Universities. This was done to ensure accuracy in records of inventory. The cost was also moderately controlled to reduce wastage and mismanagement of resources. Inventory audit was somewhat done periodically to enable the University property and resources to be secured. Hence inventory audit had moderately ensured that there is sufficient inventory turnover to avoid shortage, losses and wastage.

Further inferential analysis revealed that there was a strong significant positive relationship between inventory audit and supply management $(\beta=0.803$, $p<0.05)$. Hence the null hypothesis was rejected and alternative adapted.

\section{Conclusions}

The study concluded that there is a significant relationship between inventory audit on supply management. The inventory audits were done efficiently to ensure the accuracy of records. The cost was well controlled to ensure the reduction of wastage and mismanagement of resources in the university. The inventory audit was somewhat done periodically and also ensured that there was sufficient inventory turnover to reduce shortage, losses and wastage.

\section{Recommendations}

The study recommended that the university have room for the elimination of shortages, losses and wastage through periodic inventory audits. This can be improved by ensuring periodic inventory audits for all university property. The cost attached to negligence and mismanagement can also be transferred to the personnel and sufficient punishment should also be included to avoid loss through poor management of resources. The inventory audit policies should be clear to ensure that all the personnel in charge of handling supplies, stores, security and records areas take care of the items. The records should be accurate in relation to the inventory in the institution.

\section{REFERENCES}

Braglia, M., Gabbrielli, R., \& Zammori, F. (2013). Stock diffusion theory: a dynamic model for 
inventory control. International journal of production research, 51(10), 3018-3036.

Chemjor, R. K. (2015). Supplier evaluation criteria and procurement performance in parastatals in Kenya. University of Nairobi, Nairobi

Eaton, J., \& Kortum, S. (1999). International technology diffusion: Theory and measurement. International Economic Review, 40(3), 537-570.

Eckerson, W. W. (2010). Performance dashboards: measuring, monitoring, and managing your business. John Wiley \& Sons.

Geda, T. (2016). A Study of Supply Chain Management (SCM) Practices \& Performance at Ambassador Garment \& Trade PLC. Indira Gandhi National Open University.

Johnstone, K., Gramling, A., \& Rittenberg, L.E. (2013). Auditing: a risk-based approach to conducting a quality audit. Cengage learning.

Kravchenkova, M., \& Posazhennikova, V. (2012). Optimisation of total finished goods inventory management in decentralised organisation: $A$ Case Study on Atlas Copco Secoroc AB. Jönköping University.

Monczka, R. M., Handfield, R. B., Giunipero, L. C., $\&$ Patterson, J. L. (2015). Purchasing and supply chain management. Cengage Learning.

Oballah, D., Waiganjo, E., \& Wachiuri, W. E. (2015). Effect of inventory management practices on organisational performance in public health institutions in Kenya: A case study of Kenyatta national hospital. International Journal of Education and Research, 3(3), 703714.

Onchoke, B. N., \& Wanyoike, D. M. (2016). Influence of inventory control practices on procurement performance of agrochemicals distributors in Nakuru central sub-county, Kenya. International Journal of Economics, Finance and Management Sciences, 4(3), 117126.

Onchoke, B.N., \& Wanyoike, D.M. (2016). Influence of Inventory Control Practices on
Procurement Performance of Agrochemicals Distributors in Nakuru Central Sub-County, Kenya. International Journal of Economics, Finance and Management Sciences, 3(4), 117126.

Pan, S., Nigrelli, M., Ballot, E., Sarraj, R., \& Yang, Y. (2015). Perspectives of inventory control models in the Physical Internet: A simulation study. Computers \& Industrial Engineering, 84, 122-132.

Radosevic, M., Pasula, M., Berber, N., Neskovic, N., \& Nerandzic, B. (2013). Reengineering of supply chain process in production systems-a case study. Engineering Economics, 24(1), 7180.

Tian, F. (2017, June). A supply chain traceability system for food safety based on HACCP, blockchain \& Internet of things. In 2017 International conference on service systems and service management (pp. 1-6). IEEE.

Yadav, A.S., Maheshwari, P., \& Swami, A. (2016). Analysis of genetic algorithm and particle swarm optimisation for warehouse with supply chain management in inventory control. International Journal of Computer Applications, 145(5), 10-17.

Yadav, P. (2015). Health product supply chains in developing countries: diagnosis of the root causes of underperformance and an agenda for reform. Health Systems \& Reform, 1(2), 142154.

Yamane, T. (1973). Statistics: An introduction analysis (3rd). NY: Harper and Row. 